\title{
Kepemimpinan Partisipatif, Budaya Sekolah serta Pengaruhnya terhadap Kompetensi Pedagogik Guru Sekolah Dasar
}

\author{
Kurnia Fuji Astutik ${ }^{1}$, Erny Roesminingsih ${ }^{2}$, Meini Sondang Sumbawati ${ }^{3}$ \\ ${ }^{123}$ Universitas Negeri Surabaya, Indonesia \\ kurnia.19018@mhs.unesa.ac.id
}

\begin{abstract}
This study aims to : 1) analyze the influence of the participatory leadership on teacher pedagogical competence, 2) analyze the influence of school culture on teacher pedagogical competence, and 3) analyze the influence of the participatory leadership and school culture on teacher pedagogical competence. This research method is using a quantitative approach. The population in this study is elementary school teachers by applying proportional random sampling technique. Data were collected using a questionnaire and analyzed using linear regression and multiple regression. The results of the hypothesis test confirmed that : 1) there was a significant influence on the participatory leadership of the principal on the pedagogical competence of teachers 2 ) there was a significant influence on the school culture on the pedagogical competence of teachers and 3) the results of the multiple regression test show that the participatory leadership, and school culture together with influence the teacher's pedagogical competence. There are still many variables that can be explored to further optimize the formation of policy framework models and theoretical frameworks in increase teacher pedagogical competence.
\end{abstract}

Keywords: participatory leadership, school culture, pedagogical competencies, elementary school

Abstrak. Penelitian ini bertujuan untuk : 1) menganalisis pengaruh kepemimpinan partisipatif terhadap kompetensi pedagogik guru, 2) menganalisis pengaruh budaya sekolah terhadap kompetensi pedagogik guru, dan 3) menganalisis pengaruh kepemimpinan partisipatif dan budaya sekolah terhadap kompetensi pedagogik guru. Metode penelitian ini menggunakan pendekatan kuantitatif. Populasi dalam penelitian ini adalah guru sekolah dasar. Teknik pengambilan sampel dengan menggunakan teknik proporsional random sampling. Data dikumpulkan dengan menggunakan kuesioner dan dianalisis menggunakan regresi linier dan regresi berganda. Hasil uji hipotesis menunjukkan bahwa : 1) terdapat pengaruh yang signifikan antara kepemimpinan partisipatif terhadap kompetensi pedagogik guru 2) terdapat pengaruh yang signifikan budaya sekolah terhadap kompetensi pedagogik guru dan 3) terdapat pengaruh yang signifikan antara kepemimpinan partisipatif dan budaya sekolah terhadap kompetensi pedagogik guru. Hasil uji regresi berganda menunjukkan bahwa kepemimpinan partisipatif, dan budaya sekolah sama-sama mempengaruhi kompetensi pedagogik. Terdapat banyak variabel yang bisa dieksplorasi agar mendapatkan model kerangka kebijakan dan kerangka teoritis dalam upaya meningkatkan kompetensi pedagogik guru.

\section{Kata Kunci: Kepemimpinan Partisipatif, Budaya Sekolah, Kompetensi Pedagogik, Sekolah Dasar}

\section{PENDAHULUAN}

Secara umum Pendidikan Nasional mempunyai tujuan membangun manusia Indonesia yang berkualitas. Pembentukan pribadi yang berkualitas bergantung pada mutu pendidikan yang merupakan proses dasar dalam mencetak generasi bangsa yang bisa bertahan sesuai zamannya dan menjadi manusia yang seutuhnya (Samsudin, 2006). Berbagai upaya telah dilakukan pemerintah untuk memperbaiki kualitas pendidikan di Indonesia agar guru mempunyai kompetensi dalam melaksanakan tugasnya.

Kompetensi merupakan sekumpulan ranah pengetahuan, keterampilan, dan sikap yang menginternalisasi dalam diri guru dalam melaksanakan tugas profesionalismenya. Terdapat empat kompetensi guru yang senantiasa dipupuk dan dikembangkan diantaranya: pedagogik, kepribadian, 
profesional, dan sosial. Kompetensi pedagogik seorang guru merupakan kemampuan dalam mengelolah proses belajar mengajar serta mengembangkan potensi peserta didik (Sunhaji, 2012).

Suponco (2018) menyatakan bahwa faktor pencetus mutu pendidikan yang belum meningkat disebabkan oleh rendahnya kompetensi pedagogic guru. Guru belum mempunyai keahlian dalam merencanakan strategi pembelajaran, rendahnya inovasi dalam penelitian tindakan kelas, serta kekurangterampilan dalam mengelolah proses belajar mengajar sehingga hasil belajar siswa tidak optimal (Kasmi, 2018). Rajbhandari (2017) menyatakan bahwa faktor penghambat berkembangnya kompetensi guru adalah buruknya budaya organisasi. Merujuk konsep organisasi, maka sekolah adalah organisasi yang dibentuk untuk memudahkan proses pengajaran sehingga budaya organisasi dapat digunakan sebagai acuan dasar merumuskan pengertian budaya sekolah. Habituasi, tradisi maupun sikap dan perilaku yang dilakukan seluruh warga sekolah yang berlandaskan tatanan nilai dinamakan sebagai budaya sekolah (Peterson, D, \& Deal, 1998). Kepala sekolah mempunyai peran strategis dalm meningkatkatkan kompetensi pedagogic guru. Dengan kemampuan kepemimpinan kepala sekolah dalam memengaruhi guru untuk terus meningkatkan kompetensinya menjadi hal yang sangat penting (Rivai, 2003). Berdasarkan data TIMSS bank dunia sumber Kemendikbud 2020 pada Gambar 1.2, dipaparkan skor kompetensi guru di Indonesia belum sesuai standar. Data tersebut menjelaskan terjadi kesenjangan dalam proses belajar mengajar serta pengembangan potensi peserta didik di sekolah (Data UKG : 2019).

Skor Kompetensi Guru (UKG)

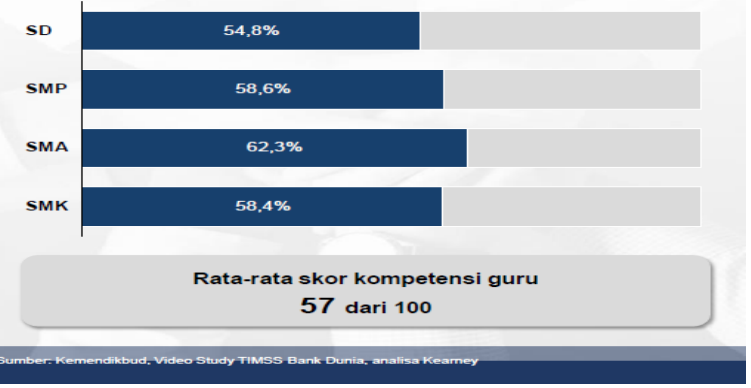

Gambar 1.2. Skor Kompetensi Guru 2019
Sekolah Dasar menduduki peringkat paling rendah diantara tingkat satuan pendidikan yang lain. Sehingga berbagai upaya dilakukan agar dapat meningkatkan kompetensi pedagogik guru diantaranya melalui gaya kepemimpinan yang partisipatif dan juga penumbuhan budaya sekolah yang baik dalam iklim yang kondusif.

\section{METODE}

Pendekatan kuantitatif merupakan pendekatan metode pada penelitian ini yang mana responden penelitiannya adalah guru sekolah dasar. Jumlah total responden 99 guru berasal dari 5 sekolah yang ditentukan oleh jumlah sampel 10\% dari total jumlah sekolah (Arikunto, 2013). Data yang terkumpul melalui kuisioner dengan pengukuran Skala Likert dianalisis menggunakan analisis regresi sederhana dan analisis regresi berganda. Sebelum dilakukan uji analisis regresi dilakukan uji persyaratan diantaranya uji normalitas, autokorelasi, multikolinieritas dan linieritas (Wijaya, 2003).

\section{HASIL DAN PEMBAHASAN}

Perhitungan validitas konstruk dilakukan pada taraf 0,05 untuk variabel kepemimpinan partisipatif telah memperoleh 25 item valid dan 5 item lainnya tidak valid. Sedangkan untuk variabel budaya organisasi dan kompetensi pedagogik mendapatkan nilai > 0,1646 yang berarti validitas kontruknya signifikan untuk semua item. Sedangkan uji reliabilitas pada taraf 0,05 diperoleh nilai alpha variabel kepemimpinan partisipatif, budaya organisasi dan kompetensi pedagogik berturut-turut 0,754 ; 0,903; dan 0,961 atau> 0,1646 berarti realibilitas dari ketiga variabel tersebut konsisten. Variabel penelitian dianalisis menggunakan SPSS 23 untuk Windows.

\section{Uji Persyaratan Analisis}

Berdasarkan keluaran

SPSS

menunjukkan nilai signifikansi variabel kepemimpinan partisipatif yaitu 0,06>0,05. Kesimpulan yang didapat adalah data variabel kepemimpinan partisipatif berdistribusi normal. Begitu juga untuk nilai signifikansi variabel budaya sekolah yaitu $0,2>0,05$. Kesimpulan yang didapat adalah data variabel budaya 
sekolah berdistribusi normal. Hasil uji autokorelasi menggunakan Durbin-Watson antara -2 dan 2 yaitu 1,687 yang dapat diartikan bahwa tidak ada autokorelasi sehingga uji hipotesis analisis regresi dapat dilakukan (Ismet, 2019).

Hasil uji multikolinieritas yaitu nilai VIF kurang dari 10 (1,386) yang menunjukkan bahawa pada data tidak terjadi multikolinieritas, sehingga analisis regresi dapat dilakukan (Ismet, 2019). Nilai Deviasi dari signifikansi linieritas adalah 0,286 yang menunjukkan bahwa nilai tersebut lebih dari 0,05 . Kesimpulan yang didapat bahwa ada hubungan linear yang signifikan antara variabel kepemimpinan partisipatif, budaya sekolah dan kompetensi pedagogik.

\section{Uji Hipotesis}

a. Pengaruh Kepemimpinan Partisipatif terhadap Kompetensi Pedagogik Guru.

Bukti empiris dari penelitian ini menunjukkan bahwa koefisien regresi sederhana antara kepemimpinan partisipatif dengan kompetensi pedagogik sebesar 0,299 berada pada kategori positif. Angka ini menyiratkan bahwa setiap tambahan $1 \%$ kepemimpinan partisipatif akan meningkatkan kompetensi pedagogik sebesar 0,299. Berdasarkan keluaran SPSS diketahui nilai sig.hit <nilai a sebesar $0,047<0,05$, yang berarti $\mathrm{H}_{0}$ ditolak. Kesimpulan yang didapat adalah terdapat pengaruh yang signifikan variabel kepemimpinan partisipatif $\left(\mathrm{X}_{1}\right)$ terhadap variabel kompetensi pedagogik guru (Y).Kesimpulan tersebut menggambarkan adanya hubungan langsung antara kedua variabel. Jika kepemimpinan semakin partisipatif maka kompetensi pedagogis guru juga akan semakin baik. Searah dengan penelitian Dwiyono (2018) dan Suponco (2018) yang menyatakan bahwa kepemimpinan partisipatif dapat meningkatkan kompetensi guru sehingga sekolah bisa berkualitas (Dwiyono, 2018) dan (Suponco, 2018)

Kepemimpinan partisipatif juga dapat membangun kompetensi pedagogik guru saat mendidik dalam pembelajaran. Mendidik dalam pembelajaran diartikan membangun karakter yang baik. Tugas utama guru adalah menciptakan lingkungan positif agar terjadi perubahan sikap menuju kebaikan (Fung, 2014). Senada dengan Purwanto et al (2019) yang menyatakan bahwa gaya kepemimpinan partisipatif melibatkan berbagai pihak pada setiap level pelaksanaan untuk menjaga kelangsungan program pendidikan karakter (Purwanto, Komariah, Kurniady, \& Sunaengsih, 2019). Tidak hanya kompetensi dalam pengembangan pendidikan karakter, pemimpin partisipatif yang menguasai teknologi dan informasi juga akan meningkatkan kompetensi literasi digital guru (Blau \& Shamir-Inbal, 2017). Kompetensi digital sangat dibutuhkan oleh seorang guru, terutama di era pandemi. Semua guru diharapkan mampu menciptakan pembelajaran berbasis digital. Berbagai penelitian yang ada menunjukkan bahwa kepemimpinan partisipatif akan meningkatkan kompetensi pedagogik guru dan akan meningkatkan kinerja guru (Siregar, Daryanto, \& Hajar, 2018).

Kepemimpinan partisipatif juga dipengaruhi oleh gender. Kepala sekolah lakilaki dalam proporsi waktu yang mereka habiskan untuk bekerja sendirian di domain tertentu. Perencanaan / penetapan tujuan adalah satu-satunya bidang di mana kepala sekolah perempuan secara signifikan berbeda dari kepala sekolah laki-laki dalam proporsi waktu yang mereka habiskan untuk bekerja sendiri. Kepala sekolah perempuan menghabiskan proporsi waktu yang lebih rendah untuk bekerja sendiri dalam merencanakan / menetapkan tujuan jika dibandingkan dengan kepala sekolah laki-laki (Sebastian, 2018). Penelitian ini menunjukkan hal yang sama karena lebih dari $50 \%$ berhubungan seks wanita. Jenis kelamin tertentu memiliki karakteristik kepemimpinan tertentu. Gaya kepemimpinan seorang perempuan lebih partisipatif dibandingkan dengan pemimpin laki-laki

b. Pengaruh Budaya Sekolah terhadap Kompetensi Pedagogik Guru.

Hasil perolehan koefisien regresi sederhana antara budaya sekolah dan kompetensi pedagogik guru sekolah sebesar 0,717 berada pada kategori positif. Berdasarkan keluaran SPSS diketahui bahwa nilai sig.hit <nilai a., yang berarti $\mathrm{H}_{0}$ ditolak. Kesimpulan yang didapat adalah terdapat pengaruh yang 
signifikan variabel budaya sekolah $\left(\mathrm{X}_{2}\right)$ terhadap variabel kompetensi pedagogik guru (Y).Kesimpulan tersebut menggambarkan adanya hubungan langsung antara kedua variabel. Jika budaya sekolah semakin baik maka kompetensi pedagogis guru akan meningkat. Sebaliknya, jika budaya sekolah menurun maka kompetensi pedagogis guru yang bersangkutan juga berkurang.

Searah dengan penelitian Arifin (2018) yang menyatakan bahwa budaya sekolah dapat meningkatkan kinerja guru dimana salah satu indikatornya adalah kompetensi pedagogik (Arifin, Juharyanto, Mustiningsih, \& Taufiq, 2018). Penelitian tentang kompetensi sosialpedagogis guru dan budaya sekolah menekankan dan mengungkapkan determinan penting guru di sekolah modern, yang dapat disebabkan oleh kompetensi tingkat tinggi mereka, memenuhi tuntutan siswa. Dengan memantau kognisi pedagogis baru, dimungkinkan untuk mengamati perubahan pentingnya kompetensi guru di bawah pengaruh masyarakat, globalisasi, tren pasar tenaga kerja, dan munculnya teknologi baru dan rasionalisasi operasi (Tohidi \& Jabbari, 2012).

Guru merupakan faktor kunci pembeda sekolah dan pembentukan identitas sekolah, sehingga tugas dan tanggungjawab guru sangat penting untuk membangun terciptanya budaya sekolah modern. Mempromosikan teori pembelajaran humanistik, makalah ini menyelidiki hubungan antara kompetensi sosialpedagogis guru dan budaya sekolah. Hasil penelitian ini penting untuk menekankan pada kompetensi sosial-pedagogik guru dalam masalah keilmuan dan profesional, dan dampaknya terhadap budaya sekolah, sehingga berkontribusi untuk menentukan peran kompetensi sosial dan pedagogik dalam budaya sekolah, mendorong perubahan dalam kehidupan- program dan penemuan studi dan pelatihan yang panjang. kurikulum sekolah tersembunyi sebagai budaya sekolah berfungsi untuk meningkatkan kesadaran dan meningkatkan kompetensi pedagogik guru. Dengan menekankan faktor kontekstual, dimungkinkan untuk berkontribusi dalam meningkatkan kualitas pembelajaran seumur hidup guru dengan penekanan yang lebih besar pada pengembangan kompetensi pedagogis (Sabli, 2017). Melalui budaya organisasi sekolah dengan menumbuhkan nilai-nilai kejujuran, keadilan, rasa tanggung jawab, rasa persaudaraan, aturan yang dibuat dan disepakati, komitmen dan kerja keras, serta kerjasama antar warga belajar secara luas (Habibi \& Raharjo, 2016). Kepala sekolah menyoroti pentingnya mempekerjakan guru yang berkualifikasi, berdedikasi, dan profesional. Mereka selanjutnya menekankan pada prosedur perekrutan (Khanal, Perry, \& Park, 2019).

\section{c. Pengaruh Kepemimpinan Partisipatif dan Budaya Sekolah tehadap Kompetensi Guru}

Penelitian ini memperoleh hasil koefisien regresi berganda untuk kepemimpinan partisipatif dan budaya sekolah terhadap kompetensi pedagogik guru sebesar 0,262 dan 0,824 pada kategori positif. Koefisien determinansi sebesar $40,6 \%$ yang artinya kepemimpinan partisipatif dan budaya sekolah keduanya berkontribusi dalam peningkatan kompetensi guru. Persamaan regressi adalah: Y $=36,438+0,262 \mathrm{X} 1+0,824 \mathrm{X} 2$. Pada variabel kepemimpinan partisipatif mendapatkan koefisien regresi 0,262 kategori positif. Hal ini menunjukkan jika variabel budaya sekolah mempunyai nilai yang tidak berubah, maka partisipasi kepemimpinan partisipatif berpengaruh positif terhadap kompetensi pedagogik sebesar 0,262. Jika terjadi peningkatan satu skor pada variabel kepemimpinan berpartisipasi maka akan mampu meningkatkan kompetensi pedagogik guru sebesar 0,262. Berdasarkan keluaran SPSS diketahui bahwa nilai sighit $<$ nilai a. $0,000<$ 0,05 . Kesimpulan yang didapat adalah adanya pengaruh yang signifikan kepemimpinan partisipatif $\left(\mathrm{X}_{1}\right)$ dan budaya sekolah $\left(\mathrm{X}_{2}\right)$ secara simultan terhadap kompetensi pedagogik guru (Y).

Pada variabel budaya sekolah mendapatkan koefisien regresi 0,824 kategori positif. Hal ini menunjukkan jika variabel kepemimpinan partisipatif mempunyai nilai yang tidak berubah, maka budaya sekolah berpengaruh positif terhadap kompetensi pedagogik sebesar 0,824. Jika terjadi 
peningkatan satu skor pada variabel budaya sekolah maka akan mampu meningkatkan kompetensi pedagogik guru sebesar 0,824. Diantara dua variabel kepemimpinan partisipatif dan budaya sekolah yang memiliki pengaruh paling dominan terhadap kompetensi pedagogik adalah variabel budaya sekolah. hal ini disebabkan karena variabel budaya sekolah mempunyai standardized beta 0,713 sedangkan kepemimpinan partisipatif sebesar 0,176.

Berdasarkan hasil penelitian Rajbhandani (2017) menunjukkan bahwa caracara yang dapat meningkatkan kompetensi guru melalui budaya sekolah, iklim organisasi, dan kepemimpinan partisipatif (Rajbhandari, Rajbhandari, Loock, \& Du Plessis, 2017). Gaya kepemimpinan harus mencakup keterampilan untuk memotivasi dan menginspirasi semua pemangku kepentingan di sekolah dan komunitas yang lebih luas. Sementara beberapa orang mungkin memiliki kecenderungan alami terhadap kepemimpinan, gagasan pelatihan kepemimpinan sangat penting. Penelitian Toll (2010) mengemukakakn bahwa kepala sekolah yang cerdas mendukung pembelajaran guru dengan memperhatikan enam bidang: harapan, demonstrasi, keramahan, kemungkinan, penyelidikan, dan budaya sekolah. Mereka dapat berlatih di semua bidang. Ketika kepala sekolah berlatih dalam praktik kepemimpinan inti, mereka lebih bersedia untuk menerima semua orang di sekolah dan menjadi lebih nyaman menerima ide dari tim bahkan ketika mereka berbeda dari mereka sendiri. Setelah kepala sekolah dapat memahami bagaimana dia mengirimkan pesan, bagaimana orang lain memahami pesannya, bagaimana dia mempengaruhi perilaku, dan bagaimana dia mengkomunikasikan perasaannya dan ide-ide untuk mempromosikan iklim positif yang memaksimalkan pembelajaran, dia siap untuk mempersonalisasi gaya kepemimpinannya. Saat kepemimpinan sekolah berubah fokus pada mandat administratif, pemimpin harus berkembang.

\section{KESIMPULAN}

Kesimpulan pada penelitian ini adalah kepemimpinan partisipatif dan budaya sekolah mempunyai pengaruh positif dan signifikan terhadap kompetensi pedagogik guru. Akan tetapi pengaruh budaya organisasi lebih besar daripada kepemimpinan partisipatif. Sehingga penelitian ini berimplikasi sebagai berikut: (1) Perlu ada ekosistem pembelajar untuk mendukung budaya organisasi, (2) Perlu adanya variasi gaya kepemimpinan yang lain yang dapat meningkatkan kompetensi pedagogik guru.

\section{SARAN}

Saran yang sesuai berdasarkan temuan serta hasil penelitian ini diantaranya: Kepemimpinan kepala sekolah diharapkan lebih partisipatif agar meningkatkan kompetensi pedagogik guru; (2) Kepala sekolah lebih menciptakan iklim belajar yang baik agar budaya sekolah dapat kondusif. (3) untuk penelitian lebih lanjut bisa menambah jumlah responden dan juga menambah variabel penelitian.

\section{DAFTAR PUSTAKA}

Arifin, I., Juharyanto, Mustiningsih, \& Taufiq, A. (2018). Islamic Crash Course as a Leadership Strategy of School Principals in Strengthening School Organizational Culture. SAGE Open, 8(3).https://doi.org/10.1177/215824401879 9849

Arikunto, S. (2013). Prosedur penelitian: suatu pendekatan praktik. Jakarta: Rineka Cipta.

Blau, I., \& Shamir-Inbal, T. (2017). Digital competences and long-term ICT integration in school culture: The perspective of elementary school leaders. Education and Information Technologies, 22(3),

769-787. https://doi.org/10.1007/s10639-015-9456-7

Dwiyono, Y. (2018). The effect of leadership style. professional competence, and work discipline toward work effectiveness. Atlantis Press, 144, 126-130. https://doi.org/10.2991/icedutech17.2018.25

Fung, F. M. G. (2014). Youth leadership in participatory school management in support of sustainable school. Association for Moral Education Conference, 1-12. 
Habibi, B., \& Raharjo, T. J. (2016). Performance of Teachers Pedagogical Vocational Business and Management in Tegal. The Journal of Educational Development, 4(1), 60-65.

Ismet, B. (2019). Handout mata kuliah statistika.

Kasmi. (2018). Meningkatkan Kompetensi Pedagogik Guru Menyusun Rencana Pelaksanaan Pembelajaran (RPP). Jurnal Global Edukasi, 2(3), 211-216.

Khanal, J., Perry, F., \& Park, S. H. (2019). Leadership practices of principals of highperforming community high schools: Evidence from Nepal. Educational Management Administration and Leadership, (2008). https://doi.org/10.1177/1741143219884076

Peterson, D, K., \& Deal, T. E. (1998). The shaping school culture fieldbook (second edi). San Francisco: Jossey Bass.

Purwanto, Komariah, A., Kurniady, D. A., \& Sunaengsih, C. (2019). Participative leadership in the implementation of character education. Opcion, 35(88), 736758.

Rajbhandari, M. M. S., Rajbhandari, S., Loock, C., \& Du Plessis, P. (2017). Enriching school culture and climate through leadership in collectivistic educational settings: cases from Nepal and South Africa. International Journal of Educational Sciences, 18(1-3), 134-146. https://doi.org/10.1080/09751122.2017.135 1076

Rivai, V. (2003). Kepemimpinan dan perilaku organisasi. Jakarta: PT Raja Grafindo Persada.

Sabli, M. (2017). 42 nd Annual ATEE Conference 2017 Book of Abstracts.

Samsudin, S. (2006). Manajemen Sumber Daya Manusia. Bandung: PT Pustaka Setia.

Sebastian, J. (2018). Gender differences in participatory leadership: An examination of principals' time spent working with others. International Journal of Education Policy and Leadership, 12 https://doi.org/10.22230/ijepl.2017v12n8a7 92

Siregar, K. U., Daryanto, E., \& Hajar, I. (2018).
The effect of organizational culture, pedagogic competence and work motivation on teacher performance at SMP Negeri Padang Bolak in North Padang Lawas district. 200, 688-692. https://doi.org/10.2991/aisteel-18.2018.150

Sunhaji. (2012). Strategi Pengembangan Kualifikasi dan Kompetensi Guru (Menurut Undang-Undang Guru \& Dosen dan Standar Nasional Pendidikan). 16, 279-297.

Suponco, P. (2018). Kepemimpinan partisipatif kepala sekolah dan kompetensi guru serta pengaruhnya terhadap mutu pendidikan. Edum Journal, 1(2), 90-95.

Tohidi, H., \& Jabbari, M. M. (2012). Organizational culture and leadership. Procedia - Social and Behavioral Sciences, 31 , 856-860. https://doi.org/10.1016/j.sbspro.2011.12.15 6

Wijaya. (2003). Statistika non parametrik. Bandung: TARSITO. 